Article

\title{
Bioactive Metabolites from the Mariana Trench Sediment-Derived Fungus Penicillium sp. SY2107
}

\author{
Sidra Kaleem ${ }^{1}$, Le Qin ${ }^{1}$, Wenwen $\mathbf{Y i}^{1}{ }^{1}$, Xiao-Yuan Lian ${ }^{2, *}$ and Zhizhen Zhang ${ }^{1, *(1)}$ \\ 1 Ocean College, Zhoushan Campus, Zhejiang University, Zhoushan 316021, China; \\ kaleemsidra85@yahoo.com (S.K.); qinle19951102@126.com (L.Q.); 18790658213@163.com (W.Y.) \\ 2 College of Pharmaceutical Sciences, Zhejiang University, Hangzhou 310058, China \\ * Correspondence: xylian@zju.edu.cn (X.-Y.L.); zzhang88@zju.edu.cn (Z.Z.); Tel.: +86-13575476388 (X.-Y.L.); \\ +86-13675859706 (Z.Z.)
}

Received: 2 May 2020; Accepted: 12 May 2020; Published: 14 May 2020

check for updates

\begin{abstract}
Mariana Trench sediments are enriched in microorganisms, however, the structures and bioactivities of their secondary metabolites are not very known. In this study, a fungus Penicillium sp. SY2107 was isolated from a sample of Mariana Trench sediment collected at a depth of $11000 \mathrm{~m}$ and an extract prepared from the culture of this fungus in rice medium showed antimicrobial activities. Chemical investigation on this active extract led to the isolation of 16 compounds, including one novel meroterpenoid, named andrastone C. Structure of the new compound was elucidated based on high-resolution electrospray ionization mass spectroscopy (HRESIMS) data, extensive nuclear magnetic resonance (NMR) spectroscopic analyses and a single crystal X-ray diffraction. The crystal structure of a known meroterpenoid andrastone B was also reported in this study. Both andrastones B and C exhibited antimicrobial activities against methicillin-resistant Staphylococcus aureus (MRSA), Escherichia coli, and Candida albicans with minimum inhibitory concentration (MIC) values in a range from 6 to $13 \mu \mathrm{g} / \mathrm{mL}$.
\end{abstract}

Keywords: hadal fungus; Penicillium sp. SY2107; andrastone C; antimicrobial activities

\section{Introduction}

Marine natural products are important sources for the discovery of novel bioactive agents and drug leads [1-5]. However, the vast majority of these reported marine natural products are obtained from the shallow-water samples and only circa $2 \%$ are isolated from the deep-sea organisms [6-8]. This statistic contrasts significantly with that of the knowledge that 95\% of the Earth's seas are greater than $1000 \mathrm{~m}$ deep and the main reason for this disparity is the limitations in obtaining deep-sea organisms $[7,8]$. With the developments in technology to access deep-sea organisms, more and more deep-sea natural products have been reported [7-9].

The deep-sea organisms under extreme conditions have had to make significant biochemical and physiological adaptations for survival, which results in the modifications of both gene regulation and metabolic pathways to produce metabolites with unique structures and bioactivities that differ from those produced by the shallow-water organisms $[7,8]$. It was reported that about $75 \%$ of deep-sea natural products possess biological activity, about $40 \%$ were drug-like, and two/three were within Known Drug Space (KDS) [8]. For example, the marine obligate Salinospora actinomycetes are found in tropical and subtropical marine sediments at the depth of up to $1100 \mathrm{~m}$ [10,11]. The genus Salinispora has become a robust model for natural product research and the secondary metabolites reported to date from the Salinospora actinomycetes are predominantly new, including salinosporamide A, a second-generation proteasome inhibitor [12]. Salinosporamide A is currently termed as marizomib under investigation in malignant glioma and relapsed-refractory multiple myeloma [13,14]. 
Mariana Trench sediments are enriched in microorganisms $[15,16]$, however, the structures and bioactivities of their secondary metabolites are not very known and need to be explored. During the course of our ongoing project for the discovery of novel bioactive agents from marine microorganisms [17-21], a fungus strain SY2107 was isolated from a sediment sample collected from the Mariana Trench at depth of $11000 \mathrm{~m}$. The extract prepared from the culture of this isolated hadal fungus in rice medium showed activities in inhibiting the growth of methicillin-resistant Staphylococcus aureus (MRSA), Escherichia coli, and Candida albicans. Chemical investigation on this active extract resulted in the isolation of 16 compounds (1-16, Figure 1), including one novel antimicrobial meroterpenoid, named andrastone $C(\mathbf{1})$. Herein, we describe the isolation, structure elucidation, and bioactive evaluation of these isolated marine natural products.

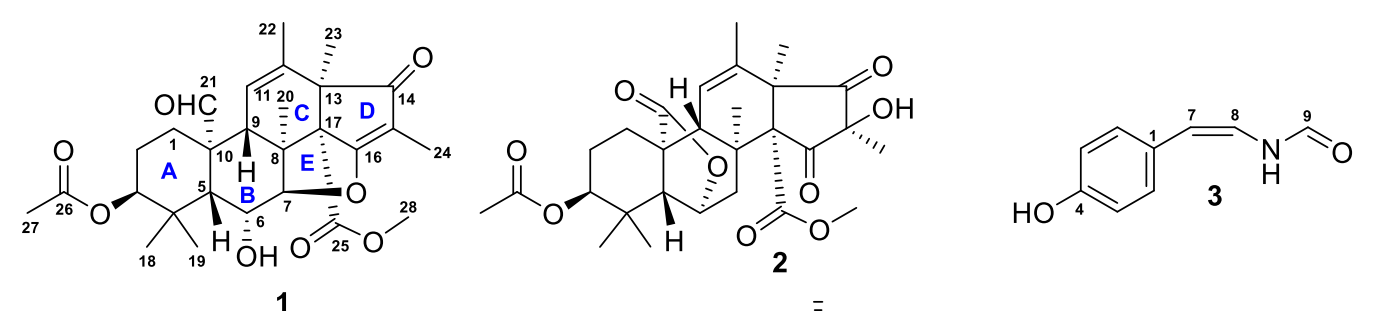

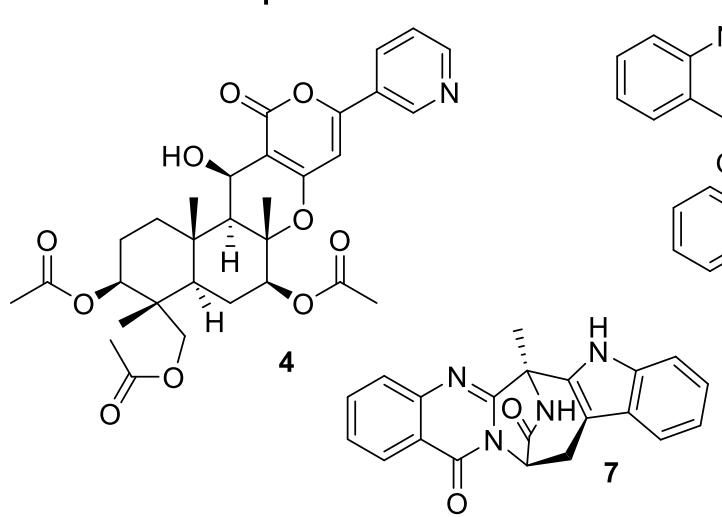<smiles>COc1ccc2c(c1)N(CC=C(C)C)C(=O)[C@@]21[C@H]2C(=O)N3CCC[C@@H]3C(=O)N2[C@@H](O)[C@@H]1O</smiles>

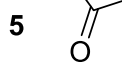<smiles>CC/C=C\C(O)[C@@H](O)C1=C(C)C(=O)C2(OC1=O)C(=O)N[C@](OC)(C(=O)c1ccccc1)[C@@H](OC)C2O</smiles>

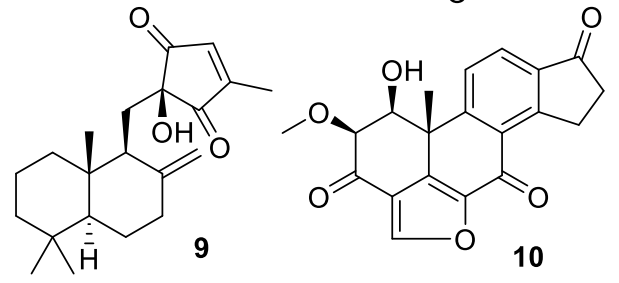<smiles>C[C@H](O)CC1=CC2=C(CO1)C(=O)[C@@](C)(O)[C@H](O)C2</smiles><smiles>CC(=O)CCCC1Cc2cccc(O)c2C(=O)O1</smiles>

12<smiles>COC(=O)c1cc(O)cc(OC)c1C(=O)c1c(O)cc(C)cc1OC</smiles>

13<smiles>COC(=O)c1cc(O)cc(OC)c1Oc1cc(C)cc(OC)c1C(=O)OC</smiles>

14<smiles>CC(C)C(=O)Nc1ccccc1C(N)=O</smiles>

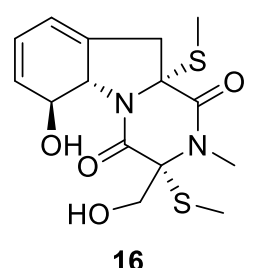

Figure 1. Structures of compounds 1-16 isolated from the culture of Penicillium sp. SY2107.

\section{Results and Discussion}

The hadal fungus SY2107 (Figure S1, Supplementary Materials) was identified as Penicillium sp. SY2107 according to the result from its internal transcribed spacer (ITS) rDNA sequence (552 bp, Figure S2) analysis, which was 100\% match to those of several Penicillium fungi (Table S1). An extract prepared from the culture of strain SY2107 in rice medium was separated by column chromatography, followed by high performance liquid chromatography (HPLC) purification, to afford compounds 1-16. 
Based on their high-resolution electrospray ionization mass spectroscopy (HRESIMS) data, extensive NMR spectroscopic analyses, and a single crystal X-ray diffraction as well as the comparison to the reported data, isolate $\mathbf{1}$ was elucidated as new meroterpenoid and 2-16 were identified as known compounds: andrastone B (16-epi-citreohybriddione A, 2) [22,23], (Z)-N-(4-hydroxystyryl)formamide (3) [24,25], pyripyropene A (4) [26], fumiquinazoline C (5) [27], spirotryprostatin C (6) [28], fumiquinazoline J (7) [29], pseurotin A (8) [30], penicilliumin B (9) [31], (-)-viridin (10) [32], monascusone A (11) [33], aspergillumarin A (12) [34], 1,2-seco-trypacidin (13) [35], di-Me 2,3'-dimethylosoate (14) [36], 2S-(2-hydroxypropanamido) benzamide (15) [37], and bisdethiobis (methylthio)gliotoxin (16) [38]. The ${ }^{13} \mathrm{C}$ and ${ }^{1} \mathrm{H}$ NMR data of $\mathbf{2 - 1 6}$ were reported in Tables S2-S7. Andrastone B (2) is a meroterpenoid recently isolated from a deep-sea-derived fungus Penicillium allii-sativi [22,23] and its crystal structure (Figure 2) [Cu K $\alpha$ radiation, Flack/Hooft parameter: -0.01(11)/0.08(10)] was reported in this study for the first time.
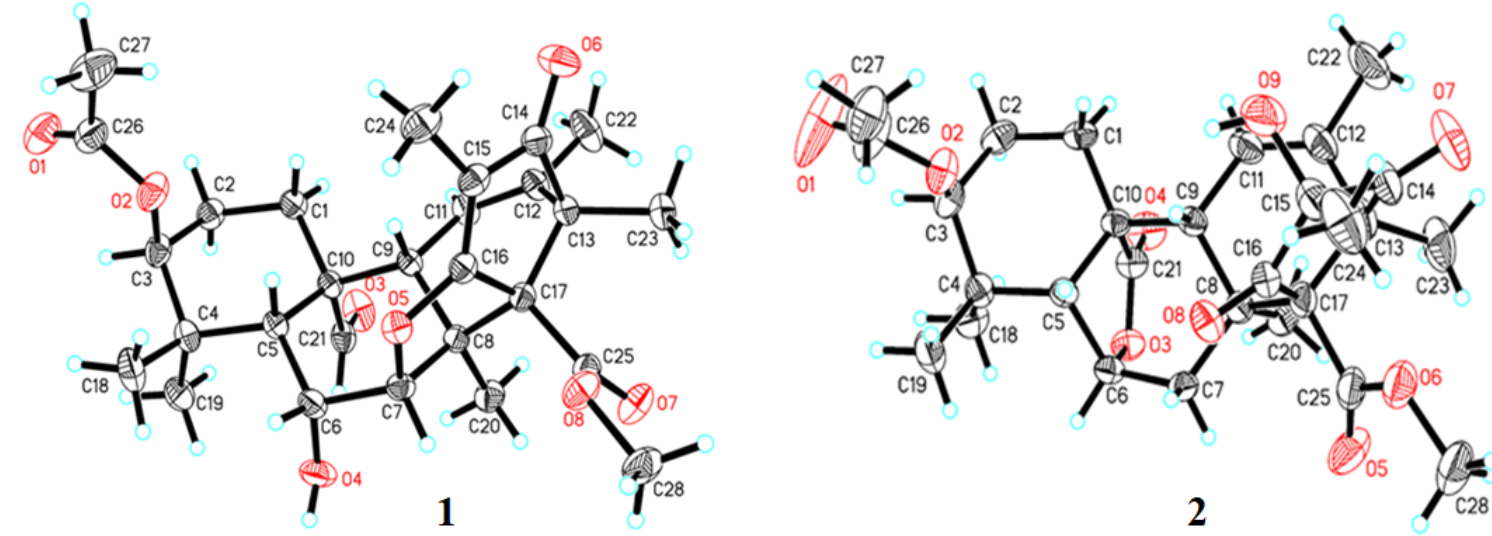

Figure 2. X-ray crystal structures of andrastones C (1) and B (2) ( $\mathrm{Cu} \mathrm{K} \alpha$ radiation).

Compound 1 was obtained as monoclinic crystals and had a molecular formula $\mathrm{C}_{28} \mathrm{H}_{36} \mathrm{O}_{8}$ deduced from its HRESIMS ions at $m / z 499.2340[\mathrm{M}-\mathrm{H}]^{-}$(calcd for $\mathrm{C}_{28} \mathrm{H}_{35} \mathrm{O}_{8}, 499.2332$ ) and $501.2482[\mathrm{M}+\mathrm{H}]^{+}$ (calcd for $\mathrm{C}_{28} \mathrm{H}_{37} \mathrm{O}_{8}, 501.2488$ ). The infrared radiation (IR) spectrum showed characteristic bands for hydroxy $\left(v_{\max } 3526 \mathrm{~cm}^{-1}\right)$ and carbonyl $\left(v_{\max } 1736,1716,1698\right.$, and $\left.1660 \mathrm{~cm}^{-1}\right)$ functional groups. The downfield ${ }^{13} \mathrm{C}$ NMR spectrum showed eight signals for four carbonyls $\left(\delta_{\mathrm{C}} 207.7,201.1,169.6,168.3\right)$ and two pairs of double bonds $\left(\delta_{C} 185.3,133.9,120.5,111.6\right)$ (Table 1$)$. These NMR data accounted for six out of the 11 degrees of unsaturation required by the molecular formula and the remaining five suggested that the structure of $\mathbf{1}$ had five rings. In the correlation spectroscopy (COSY) spectrum, three spin systems of $\mathrm{H}_{2}-2\left(\delta_{\mathrm{H}} 1.47, \mathrm{~m}\right)$ with $\mathrm{H}_{2}-1\left(\delta_{\mathrm{H}} 2.31, \mathrm{dt}, 13.5,3.2 \mathrm{~Hz} ; 0.79, \mathrm{td}, 13.5,4.5 \mathrm{~Hz}\right)$ and H-3 $\left(\delta_{\mathrm{H}} 4.42, \mathrm{t}, 3.1 \mathrm{~Hz}\right), \mathrm{H}-6\left(\delta_{\mathrm{H}} 4.52, \mathrm{t}, 2.8 \mathrm{~Hz}\right)$ with H-5 $(1.79, \mathrm{~d}, 2.8 \mathrm{~Hz})$ and $\mathrm{H}-7\left(\delta_{\mathrm{H}} 4.67, \mathrm{~d}, 2.8 \mathrm{~Hz}\right)$, and $\mathrm{H}-9\left(\delta_{\mathrm{H}} 2.05, \mathrm{br} \mathrm{s}\right)$ with $\mathrm{H}-11\left(\delta_{\mathrm{H}} 5.60\right.$, br s) were observed (Figure 3$)$. Heteronuclear multiple bond correlation $(\mathrm{HMBC})$ spectrum showed the following correlations (Figure 3$)$ : H-1 $\left(\delta_{\mathrm{H}} 0.79\right)$ with C-2 $\left(\delta_{\mathrm{C}} 22.4\right), \mathrm{C}-10\left(\delta_{\mathrm{C}} 51.5\right)$, and C-21 $\left(\delta_{\mathrm{C}} 207.7\right) ; \mathrm{H}-3$ with C-1 $\left(\delta_{\mathrm{C}} 28.5\right), \mathrm{C}-5\left(\delta_{\mathrm{C}} 45.8\right)$, and C-26 $\left(\delta_{\mathrm{C}}\right.$ $169.6) ; \mathrm{H}-5$ with $\mathrm{C}-4\left(\delta_{\mathrm{C}} 36.8\right), \mathrm{C}-6\left(\delta_{\mathrm{C}} 66.0\right), \mathrm{C}-10, \mathrm{C}-19\left(\delta_{\mathrm{C}} 23.0\right)$, and C-21; H-6 with C-7 $\left(\delta_{\mathrm{C}} 91.9\right), \mathrm{C}-8$ $\left(\delta_{C} 45.6\right)$, and C-10; H-7 with C-5, C-6, C-8, and C-9 $\left(\delta_{C} 50.1\right)$; H-9 with C-11 $\left(\delta_{C} 120.5\right)$ and C-12 $\left(\delta_{C}\right.$ $133.9) ; \mathrm{H}-11$ with $\mathrm{C}-10, \mathrm{C}-13\left(\delta_{\mathrm{C}} 52.9\right)$, and $\mathrm{C}-22\left(\delta_{\mathrm{C}} 20.2\right) ; \mathrm{H}_{3}-18\left(\delta_{\mathrm{H}} 0.97, \mathrm{~s}\right)$ with $\mathrm{C}-3\left(\delta_{\mathrm{C}} 77.4\right), \mathrm{C}-4, \mathrm{C}-5$, and $\mathrm{C}-19 ; \mathrm{H}_{3}-19\left(\delta_{\mathrm{H}} 1.09\right.$, s) with C-3, C-4, C-5, and C-18 $\left(\delta_{\mathrm{C}} 25.3\right) ; \mathrm{H}_{3}-20\left(\delta_{\mathrm{H}} 1.12\right.$, s) with C-7, C-8, C-9, and $\mathrm{C}-17\left(\delta_{\mathrm{C}} 68.5\right) ; \mathrm{H}_{3}-21\left(\delta_{\mathrm{H}} 10.55\right.$, s) with $\mathrm{C}-1, \mathrm{C}-10$, and $\mathrm{C}-20\left(\delta_{\mathrm{C}} 15.5\right) ; \mathrm{H}_{3}-22\left(\delta_{\mathrm{H}} 1.75, \mathrm{~s}\right)$ with C-11, $\mathrm{C}-12$, and $\mathrm{C}-13 ; \mathrm{H}_{3}-23\left(\delta_{\mathrm{H}} 1.13\right.$, s) with $\mathrm{C}-12, \mathrm{C}-13$, and $\mathrm{C}-17$; and $\mathrm{H}_{3}-27\left(\delta_{\mathrm{H}} 1.93, \mathrm{~s}\right)$ with $\mathrm{C}-26$. These COSY and $\mathrm{HMBC}$ correlations established the partial structure of rings $\mathrm{A}-\mathrm{C}$ (a 6/6/6 tricyclic fusion) with an acetyl group at C-3, two oxymethines at C- 6 and C-7, an aldehyde group at C-21, and five methyls at C-18, C-19, C-20, C-22, and C-23, respectively. In addition, HMBC correlations of $\mathrm{H}_{3}-23$ with C-12, C-13, C-14 $\left(\delta_{\mathrm{C}} 201.1\right)$, and C-17, $\mathrm{H}_{3}-24\left(\delta_{\mathrm{H}} 1.57\right.$, s) with C-14, C-15 $\left(\delta_{\mathrm{C}} 111.6\right), \mathrm{C}-16\left(\delta_{\mathrm{C}} 185.3\right)$, 
and $\mathrm{C}-25\left(\delta_{\mathrm{C}} 168.3\right)$, and $\mathrm{H}_{3}-28\left(\delta_{\mathrm{H}} 3.69\right.$, s) with $\mathrm{C}-25$ were also observed, indicating the C/D/E ring juncture with a keto at C-14, a methyl at C-24, and a methoxy at C-28. Although no HMBC correlation of H-7 with C-16 was observed, the downfield chemical shifts at $\delta_{C} 91.9$ for C-7 and $\delta_{C} 185.3$ for C-16 suggested a five-membered ether ring for $\mathrm{E}$, which was confirmed by the crystal structure (Figure 2) of 1 obtained from a single crystal X-ray diffraction.

Table $1 .{ }^{13} \mathrm{C}$ and ${ }^{1} \mathrm{H}$ NMR data of andrastone $\mathrm{C}\left(\mathbf{1}\right.$, in dimethylsulfoxide- $\left.d_{6}\right)$.

\begin{tabular}{cccccc}
\hline No. & ${ }^{13} \mathrm{C}$, Type & ${ }^{\mathbf{1}} \mathbf{H}(\mathbf{J}$ in $\mathbf{H z})$ & No. & ${ }^{13} \mathrm{C}$, Type & ${ }^{\mathbf{1}} \mathbf{H}(\boldsymbol{J}$ in $\mathbf{H z})$ \\
\hline 1 & $28.5, \mathrm{CH}_{2}$ & $\alpha: 2.31 \mathrm{dt}(13.5,3.2) ; \beta: 0.79, \mathrm{td}(13.5,4.5)$ & 15 & $111.6, \mathrm{C}$ & - \\
\hline 2 & $22.4, \mathrm{CH}_{2}$ & $1.47, \mathrm{~m}$ & 16 & $185.3, \mathrm{C}$ & - \\
\hline 3 & $77.4, \mathrm{CH}$ & $4.42, \mathrm{t}(3.1)$ & 17 & $68.5, \mathrm{C}$ & - \\
\hline 4 & $36.8, \mathrm{C}$ & - & 18 & $25.3, \mathrm{CH}_{3}$ & $0.97, \mathrm{~s}$ \\
\hline 5 & $45.8, \mathrm{CH}$ & $1.79, \mathrm{~d}(2.8)$ & 19 & $23.0, \mathrm{CH}_{3}$ & $1.09, \mathrm{~s}$ \\
\hline 6 & $66.0, \mathrm{CH}$ & $4.52, \mathrm{t}(2.8)$ & 20 & $15.5, \mathrm{CH}_{3}$ & $1.12, \mathrm{~s}$ \\
\hline 7 & $91.9, \mathrm{CH}$ & $4.67, \mathrm{~d}(2.8)$ & 21 & $207.7, \mathrm{CH}$ & $10.55, \mathrm{~s}$ \\
\hline 8 & $45.6, \mathrm{C}$ & - & 22 & $20.2, \mathrm{CH}_{3}$ & $1.75, \mathrm{~s}$ \\
\hline 9 & $50.1, \mathrm{CH}$ & $2.05, \mathrm{br} \mathrm{s}$ & 23 & $20.5, \mathrm{CH}_{3}$ & $1.13, \mathrm{~s}$ \\
\hline 10 & $51.5, \mathrm{C}$ & - & 24 & $5.4, \mathrm{CH}_{3}$ & $1.57, \mathrm{~s}$ \\
\hline 11 & $120.5, \mathrm{CH}$ & $5.60, \mathrm{br} \mathrm{s}$ & 25 & $168.3, \mathrm{C}$ & - \\
\hline 12 & $133.9, \mathrm{C}$ & - & 26 & $169.6, \mathrm{C}$ & - \\
\hline 13 & $52.9, \mathrm{C}$ & - & 27 & $20.6, \mathrm{CH}_{3}$ & $1.93, \mathrm{~s}$ \\
\hline 14 & $201.1, \mathrm{C}$ & - & 28 & $52.4, \mathrm{CH}_{3}$ & $3.69, \mathrm{~s}$ \\
\hline
\end{tabular}

Note: No.: number, J: coupling constant, s: singlet, d: doublet, m: multiplet, br s: broad singlet.
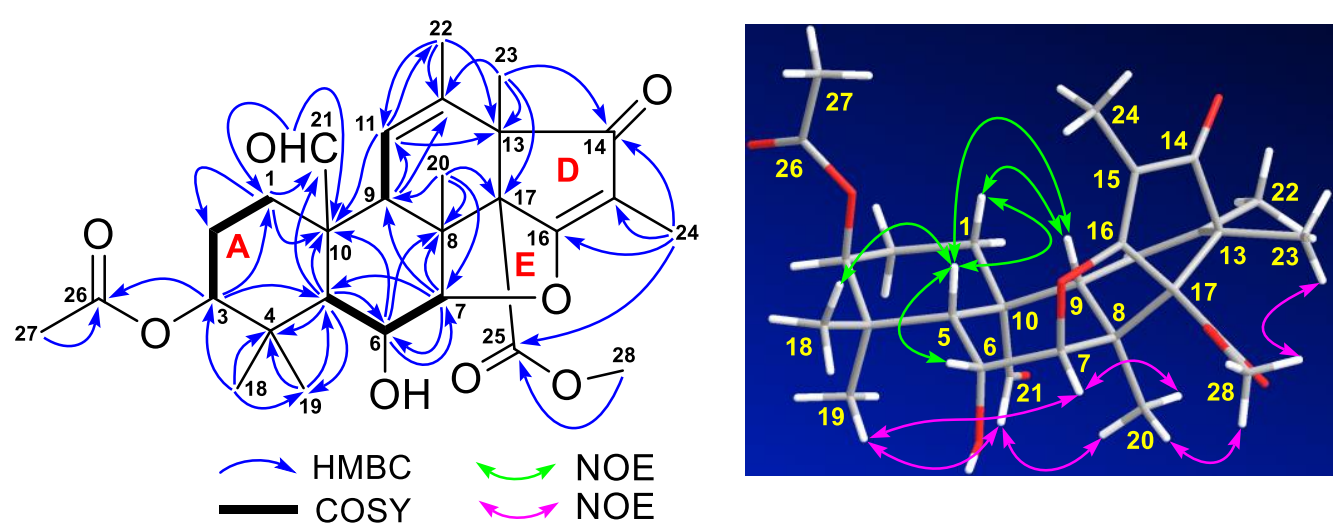

Figure 3. Correlation spectroscopy (COSY), key heteronuclear multiple bond correlation (HMBC), and nuclear Overhauser effect (NOE) correlations of andrastone C (1).

The relative configuration of $\mathbf{1}$ was assigned by nuclear Overhauser effect spectroscopy (NOESY) experiment. NOE correlations (Figure 3) of $\mathrm{H}-1 \beta\left(\delta_{\mathrm{H}} 0.79\right)$ with $\mathrm{H}-5$ and $\mathrm{H}-9$ and $\mathrm{H}-5$ with $\mathrm{H}-6, \mathrm{H}-9$, and $\mathrm{H}_{3}-18$ indicated a $\beta$-orientation for these protons, while NOE correlations of $\mathrm{H}-7$ with $\mathrm{H}_{3}-19$ and $\mathrm{H}_{3}-20, \mathrm{H}_{3}-21$ with $\mathrm{H}_{3}-19$ and $\mathrm{H}_{3}-20$, and $\mathrm{H}_{3}-28$ with $\mathrm{H}_{3}-20$ and $\mathrm{H}_{3}-23$ were suggestive of a $\alpha$-orientation for these protons. The relative configuration was confirmed and the absolute configuration of 1 was determined as $3 S, 5 R, 6 R, 7 R, 8 S, 9 R, 10 R, 13 R, 17 R$ by a single crystal $X$-ray diffraction analysis [Cu K $\alpha$ radiation, Flack/Hooft parameter: -0.02(8)/-0.00(6)] (Figure 2). Based on the foregoing evidences, compound 1 was elucidated as a new analogue of andrastone B (2), named andrastone C. Its ${ }^{13} \mathrm{C}$ and ${ }^{1} \mathrm{H}$ NMR data (Table 1) were assigned based on the heteronuclear multiple quantum correlation 
(HMQC), COSY, HMBC, and NOE correlations. To the best of our knowledge, andrastone C is the first example of this type of meroterpenoids with a five-membered ether ring (ring $\mathrm{E}$ ).

Compounds 1-16 were tested for their antimicrobial activities against methicillin-resistant Staphylococcus aureus (MRSA), Escherichia coli, and Candida albicans by the micro-broth dilution method [39]. Vancomycin (an antibiotic against MRSA), gentamicin (an antibiotic against both Gram-positive and negative bacteria), and amphotericin B (an antifungal drug) were used as positive controls. The results (Table 2) showed that both andrastones C (1) and B (2) had antimicrobial activities with minimum inhibitory concentration (MIC) values of 8 and $9 \mu \mathrm{g} / \mathrm{mL}$ against MRSA, 8 and $12 \mu \mathrm{g} / \mathrm{mL}$ against E. coli, and 13 and $6 \mu \mathrm{g} / \mathrm{mL}$ against C. albicans, respectively. Known compounds 3-12 also showed antimicrobial activities against MRSA, E. coli, and C. albicans with MIC values in a range from 9 to $22 \mu \mathrm{g} / \mathrm{mL}$, while compounds 13-16 only showed antibacterial activities against MRSA and E. coli with MIC values of $22-38 \mu \mathrm{g} / \mathrm{mL}$.

Table 2. Antimicrobial activities of compounds 1-16 $(\mu \mathrm{g} / \mathrm{mL})$.

\begin{tabular}{|c|c|c|c|c|c|c|}
\hline \multirow{2}{*}{ Compounds } & \multicolumn{2}{|c|}{ MRSA } & \multicolumn{2}{|c|}{ E. coli } & \multicolumn{2}{|c|}{ Candida albicans } \\
\hline & MIC & MBC & MIC & MBC & MIC & MBC \\
\hline 1 & 8 & 15 & 8 & 13 & 13 & 17 \\
\hline 2 & 9 & 15 & 12 & 19 & 6 & 10 \\
\hline 3 & 13 & 18 & 10 & 20 & 9 & 16 \\
\hline 4 & 14 & 20 & 13 & 18 & 14 & 20 \\
\hline 5 & 15 & 22 & 9 & 16 & 12 & 18 \\
\hline 6 & 11 & 20 & 9 & 14 & 13 & 20 \\
\hline 7 & 15 & 20 & 16 & 23 & 15 & 21 \\
\hline 8 & 17 & 23 & 16 & 22 & 10 & 18 \\
\hline 9 & 12 & 18 & 13 & 21 & 15 & 24 \\
\hline 10 & 20 & 26 & 22 & 28 & 14 & 26 \\
\hline 11 & 9 & 15 & 11 & 19 & 17 & 28 \\
\hline 12 & 15 & 26 & 14 & 23 & 18 & 28 \\
\hline 13 & 28 & 36 & 22 & 30 & $>50$ & $>50$ \\
\hline 14 & 33 & 39 & 38 & 42 & $>50$ & $>50$ \\
\hline 15 & 32 & 41 & 34 & 45 & $>50$ & $>50$ \\
\hline 16 & 27 & 33 & 26 & 32 & $>50$ & $>50$ \\
\hline Gentamicin & 3 & 7 & 0.5 & 3 & NT & NT \\
\hline Vancomycin & 0.5 & 3 & NT & NT & NT & NT \\
\hline Amphotericin B & NT & NT & NT & NT & 3 & 6 \\
\hline
\end{tabular}

MIC: minimum inhibitory concentration; MBC: minimum bactericidal concentration; NT: No testing.

Compounds 1-3 were also evaluated for their activities in inhibiting the proliferation of human glioma U251 and U87MG cells using the sulforhodamine B (SRB) assay [40]. Doxorubicin (DOX, a chemotherapeutic drug) was used as a positive control. (Z)-N-(4-hydroxystyryl)formamide (3) exhibited antiproliferative activity against U251 and U87MG cells with $\mathrm{IC}_{50}$ values of $17.0 \pm 2.9$ and $39.8 \pm 1.6 \mu \mathrm{M}$, respectively. Both andrastones $\mathrm{C}(\mathbf{1})$ and $\mathrm{B}(2)$ showed no antiproliferative activity at a concentration of $50 \mu \mathrm{M}$. 


\section{Materials and Methods}

\subsection{General Experimental Procedures}

Optical rotation was measured on an Autopol I polarimeter (Rudolph Research Analytical). Ultraviolet (UV) and IR spectra were recorded on a METASH UV-8000 spectrometer (Shanghai METASH Instruments Co. Ltd., Shanghai, China) and a Bruker TENSOR II high performance FT-IR spectrometer (Bruker, Karlsruhe, Germany), respectively. HRESIMS data were obtained from an Agilent 6230 Time of Flight Liquid Chromatography/Mass Spectrometry (TOF LC/MS) spectrometer. NMR spectra were acquired on a JEOL 600 spectrometer (Japan) using standard programs and acquisition parameters and chemical shifts were expressed in $\delta(\mathrm{ppm})$. X-ray diffraction analysis was performed on an Xcalibur Atlas Gemini Ultra diffractometer (Agilent Technologies) with $\mathrm{Cu}$ $\mathrm{K} \alpha$ radiation $(\lambda=1.54184 \AA$ ) at $100 \mathrm{~K}$. Silica gel (100-200 mesh, Qingdao Haiyang Chemical Co., China), octadecyl-functionalized silica gel (ODS, Cosmosil 75C 18 -Prep, Nacalai Tesque Inc., Japan), and Sephadex LH-20 (GE Healthcare, Sweden) were used for open column chromatography. High performance liquid chromatography (HPLC) separation was carried out on an Agilent 1260 HPLC system with a diode array detector (DAD) using a Zorbax SB-C ${ }_{18}$ column $(250 \times 9.4 \mathrm{~mm}, 5 \mu \mathrm{m}$, Agilent Technologies, Palo Alto, USA) or a CXTH LC-3000 HPLC system (Beijing Chuangxin Tongheng Science \& Technology Co. Ltd. China) using a CT-30 column (Fuji- C $_{18}, 280 \times 30 \mathrm{~mm}, 10 \mu \mathrm{m}$ ). All solvents used for this study were ordered from the Shanghai Lingfeng Co., Ltd. (Shanghai, China). Methicillin-resistant Staphylococcus aureus (MRSA) ATCC 43300, Escherichia coli ATCC 25922, and Candida albicans ATCC 10231 were provided by Drs. Zhongjun Ma, Pinmei Wang, and Bin Wu, respectively. Human glioma U251 (XB-0439) and U87MG (JDS-2568) cells were purchased from the Cell Bank of the Chinese Academy of Sciences. Vancomycin (>98.0\%), gentamicin (99.6\%), and amphotericin B (99.0\%) were obtained from the Meilune Biotechnology Co. Ltd. (Dalian, China), and doxorubicin (DOX, >98.0\%) from Sigma-Aldrich. Sea salt was bought from the Zhejiang Province Salt Industry Group Company, Ltd. Artificial seawater (sea salt $35 \mathrm{~g}$, water $1 \mathrm{~L}$ ) was made in the laboratory. Different culture media were prepared in the laboratory, including B solid medium (soluble starch $20 \mathrm{~g}, \mathrm{KNO}_{3}$ $1 \mathrm{~g}, \mathrm{MgSO}_{4} \cdot 7 \mathrm{H}_{2} \mathrm{O} 0.5 \mathrm{~g}, \mathrm{NaCl} 0.5 \mathrm{~g}, \mathrm{~K}_{2} \mathrm{HPO}_{4} 0.5 \mathrm{~g}, \mathrm{FeSO}_{4} 0.01 \mathrm{~g}$, agar $15 \mathrm{~g}$, water $1 \mathrm{~L}$, pH 6-7), BY solid medium (soluble starch $20 \mathrm{~g}, \mathrm{KNO}_{3} 1 \mathrm{~g}, \mathrm{MgSO}_{4} \cdot 7 \mathrm{H}_{2} \mathrm{O} 0.5 \mathrm{~g}, \mathrm{NaCl} 0.5 \mathrm{~g}, \mathrm{~K}_{2} \mathrm{HPO}_{4} 0.5 \mathrm{~g}, \mathrm{FeSO}_{4} 0.01 \mathrm{~g}$, agar $15 \mathrm{~g}$, sea salt $35 \mathrm{~g}$, water $1 \mathrm{~L}, \mathrm{pH} 6-7$ ), PDA (potato dextrose agar) medium (potatoes $200 \mathrm{~g}$, glucose $20 \mathrm{~g}$, agar $20 \mathrm{~g}$, boiled into $1 \mathrm{~L}$ of water for $15 \mathrm{~min}$, pH 6-7), PDAY medium (potatoes $200 \mathrm{~g}$, glucose $20 \mathrm{~g}$, agar $20 \mathrm{~g}$, sea salt $35 \mathrm{~g}$, boiled into $1 \mathrm{~L}$ of water for $15 \mathrm{~min}, \mathrm{pH}$ 6-7), E solid medium (yeast $1.0 \mathrm{~g}$, tryptone $5.0 \mathrm{~g}, \mathrm{FeCl}_{3} \cdot 6 \mathrm{H}_{2} \mathrm{O} 0.17 \mathrm{~g}, \mathrm{KH}_{2} \mathrm{PO}_{4} 0.12 \mathrm{~g}$, agar $15 \mathrm{~g}$, water $1 \mathrm{~L}$, $\mathrm{pH}$ 6-7), EY solid medium (yeast $1.0 \mathrm{~g}$, tryptone $5.0 \mathrm{~g}, \mathrm{FeCl}_{3} \cdot 6 \mathrm{H}_{2} \mathrm{O} 0.17 \mathrm{~g}, \mathrm{KH}_{2} \mathrm{PO}_{4} 0.12 \mathrm{~g}$, agar $15 \mathrm{~g}$, sea salt $35 \mathrm{~g}$, water $1 \mathrm{~L}$, pH 6-7), ISP2 solid medium (yeast extract $4 \mathrm{~g}$, malt extract $10 \mathrm{~g}$, dextrose $4 \mathrm{~g}$, peptone $5 \mathrm{~g}$, agar $20 \mathrm{~g}$, water $1 \mathrm{~L}, \mathrm{pH}$ 6-7), ISP2Y solid medium (yeast extract $4 \mathrm{~g}$, malt extract $10 \mathrm{~g}$, dextrose $4 \mathrm{~g}$, peptone $5 \mathrm{~g}$, agar $20 \mathrm{~g}$, sea salt $35 \mathrm{~g}$, water $1 \mathrm{~L}$, pH 6-7), ISP4 solid medium (soluble starch $10 \mathrm{~g}, \mathrm{~K}_{2} \mathrm{HPO}_{4} 1 \mathrm{~g}$, $\mathrm{MgSO}_{4} \cdot 7 \mathrm{H}_{2} \mathrm{O} 1 \mathrm{~g}, \mathrm{NaCl} 1 \mathrm{~g},\left(\mathrm{NH}_{4}\right)_{2} \mathrm{SO}_{4} 2 \mathrm{~g}, \mathrm{CaCO}_{3} 2 \mathrm{~g}, \mathrm{FeSO}_{4} 1 \mathrm{mg}, \mathrm{MnCl}_{2} 1 \mathrm{mg}, \mathrm{ZnSO}_{4} 1 \mathrm{mg}$, agar $20 \mathrm{~g}$, water $1 \mathrm{~L}$, pH 6-7), ISP4Y solid medium (soluble starch $10 \mathrm{~g}, \mathrm{~K}_{2} \mathrm{HPO}_{4} 1 \mathrm{~g}, \mathrm{MgSO}_{4} \cdot 7 \mathrm{H}_{2} \mathrm{O} 1 \mathrm{~g}, \mathrm{NaCl}$ $1 \mathrm{~g}$, $\left(\mathrm{NH}_{4}\right)_{2} \mathrm{SO}_{4} 2 \mathrm{~g}, \mathrm{CaCO}_{3} 2 \mathrm{~g}, \mathrm{FeSO}_{4} 1 \mathrm{mg}, \mathrm{MnCl}_{2} 1 \mathrm{mg}, \mathrm{ZnSO}_{4} 1 \mathrm{mg}$, agar $20 \mathrm{~g}$, sea salt $35 \mathrm{~g}$, water $1 \mathrm{~L}$, and $\mathrm{pH} 6-7)$.

\subsection{Isolation and Identification of Strain SY2107}

Strain SY2107 was isolated from a sediment sample, which was collected from the Mariana Trench at depth $11000 \mathrm{~m}$ on November, 2018. Briefly, the sediment was air dried at $28^{\circ} \mathrm{C}$ for 7 days and the dried sample $(1.0 \mathrm{~g})$ was diluted with sterile water to make dilutions of $10^{-2}, 10^{-3}$, and $10^{-4} \mathrm{~g} / \mathrm{mL}$. Each dilution $(200 \mu \mathrm{L})$ was covered on the surface of ten different media of B, BY, D, DY, E, EY, ISP2, ISP2Y, ISP4, and ISP4Y in Petri dishes and then incubated at $28^{\circ} \mathrm{C}$ for 14 days. The single pure colony of SY2107 was picked from the $10^{-2} \mathrm{~g} / \mathrm{mL}$ suspension in ISP2Y solid medium and then transferred to 
another ISP2Y solid medium plate. After growth for another 7 days at $28^{\circ} \mathrm{C}$, the single colony (SY2107) that grew well was transferred onto an ISP2Y solid medium slant and stored at $4{ }^{\circ} \mathrm{C}$ for further study.

The strain SY2107 was identified by internal transcribed spacer (ITS) rDNA sequence analysis conducted by Legenomics (Hangzhou, China). The ITS rDNA sequence of strain SY2107 was compared to those in the GenBank using nucleotide BLAST (Basic Local Alignment Search Tool) and the rDNA sequence data of strain SY2107 has been deposited in GenBank with accession number MT355647. The strain Penicillium sp. SY 2107 was preserved at the Laboratory of Institute of Marine Biology and Pharmacology, Ocean College, Zhoushan Campus, Zhejiang University, China.

\subsection{Scale Up Culture of Strain SY2107}

Pure colony of strain SY2107 from the ISP2Y solid medium slant was inoculated into a $500 \mathrm{~mL}$ Erlenmeyer flask, which contained $250 \mathrm{~mL}$ ISP2Y liquid medium and then incubated for 3 days in a shaker $\left(180 \mathrm{rpm}, 28^{\circ} \mathrm{C}\right)$ to produce seed broth. The seed broth $(10 \mathrm{~mL})$ was then transferred into rice medium ( $40 \mathrm{~g}$ rice and $60 \mathrm{~mL}$ artificial seawater) in $500 \mathrm{~mL}$ Erlenmeyer flask and then all flasks were incubated at $28^{\circ} \mathrm{C}$ for 30 days in a static state. A total of 200 cultured flasks were prepared for this study.

\subsection{Isolation of Compounds $\mathbf{1 - 1 6}$}

The culture of strain SY2107 in rice medium in each flask was extracted with EtOAc $(250 \mathrm{~mL})$ three times. The combined EtOAc extract was dried in vacuo to give an extract $(70 \mathrm{~g})$. This extract was fractionated on a column $(160 \times 10 \mathrm{~cm})$ of silica gel $(1200 \mathrm{~g})$ eluting with a mixture $(1000 \mathrm{~mL})$ of cyclohexane and EtOAc in different ratios $(10: 1,51,2: 1,1: 1$, and 1:2) to give five fractions fractions A-E.

Fraction A was separated by using an Agilent 1260 HPLC system with a Zorbax SB-C 18 column $\left(250 \times 9.4 \mathrm{~mm}, 5 \mu \mathrm{m}\right.$; UV detection: $230 \mathrm{~nm}$; mobile phase: $\mathrm{MeOH} / \mathrm{H}_{2} \mathrm{O}, 65 / 35$; flow rate: $\left.1.0 \mathrm{~mL} / \mathrm{min}\right)$ to give $\mathbf{1 0}\left(5.0 \mathrm{mg}, \mathrm{t}_{\mathrm{R}} 29.6 \mathrm{~min}\right)$ and $\mathbf{1 4}\left(6.7 \mathrm{mg}, \mathrm{t}_{\mathrm{R}} 34.5 \mathrm{~min}\right)$.

Fraction B was first separated on a column $(450 \times 25 \mathrm{~mm})$ of ODS $(150 \mathrm{~g})$ eluting with $60 \%, 70 \%$, and $80 \% \mathrm{MeOH}$ (each $1000 \mathrm{~mL}$ ) to yield three subfractions $\mathrm{B}_{1}-\mathrm{B}_{3}$, respectively. Subfraction $\mathrm{B}_{1}$ was further separated on the CT-30 column (UV detection: $210 \mathrm{~nm}$; mobile phase: $\mathrm{MeOH} / \mathrm{H}_{2} \mathrm{O}, 59 / 41$; flow rate: $10 \mathrm{~mL} / \mathrm{min})$ to give $\mathbf{1 6}\left(15.2 \mathrm{mg}\right.$, $\left.t_{\mathrm{R}} 36.4 \mathrm{~min}\right)$. Subfraction $\mathrm{B}_{2}$ was also separated on the same CT-30 column using the same flow rate and same UV detection wavelength and a different mobile phase of $\mathrm{MeOH} / \mathrm{H}_{2} \mathrm{O}(80 / 20)$ to give $4\left(10.1 \mathrm{mg} ; \mathrm{t}_{\mathrm{R}} 18.6 \mathrm{~min}\right)$ and $13\left(22.0 \mathrm{mg} ; \mathrm{t}_{\mathrm{R}} 27.5 \mathrm{~min}\right)$. In the same way, Subfraction $B_{3}$ was separated on the CT-30 column (UV detection: $210 \mathrm{~nm}$; mobile phase: $\mathrm{MeOH} / \mathrm{H}_{2} \mathrm{O}, 67 / 33$; flow rate: $10 \mathrm{~mL} / \mathrm{min}$ ) to give parts $\mathrm{B}_{3 \mathrm{a}}$ and $\mathrm{B}_{3 \mathrm{~b}}$. Part $\mathrm{B}_{3 \mathrm{a}}$ was further separated via the Zorbax SB- $\mathrm{C}_{18}$ column (UV detection: $230 \mathrm{~nm}$; mobile phase: $\mathrm{ACN} / \mathrm{H}_{2} \mathrm{O}, 45 / 55$; flow rate: $1.0 \mathrm{~mL} / \mathrm{min})$ to give $\mathbf{9}\left(7.0 \mathrm{mg}, \mathrm{t}_{\mathrm{R}} 38.5 \mathrm{~min}\right)$ and $\mathbf{2}\left(2.5 \mathrm{mg} ; \mathrm{t}_{\mathrm{R}} 42.4 \mathrm{~min}\right)$. By using the same Zorbax $\mathrm{SB}-\mathrm{C}_{18}$ column at the same flow rate with different UV detection of $254 \mathrm{~nm}$ and mobile phase of $\mathrm{ACN} / \mathrm{H}_{2} \mathrm{O}$ (42/58), compounds $\mathbf{1}\left(2.8 \mathrm{mg}, \mathrm{t}_{\mathrm{R}} 43.8 \mathrm{~min}\right)$ and $\mathbf{3}\left(7 \mathrm{mg}, \mathrm{t}_{\mathrm{R}} 35.2 \mathrm{~min}\right)$ were purified from part $\mathrm{B}_{3 \mathrm{~b}}$.

Similarly, fraction C was fractionated on a CT-30 column $(280 \times 30 \mathrm{~mm}, 10 \mu \mathrm{m}$; UV detection: $210 \mathrm{~nm}$; mobile phase: $\mathrm{MeOH} / \mathrm{H}_{2} \mathrm{O}, 50 / 50$; flow rate: $10 \mathrm{~mL} / \mathrm{min}$ ) by a CXTH LC-3000 HPLC system to afford parts $C_{1}$ and $C_{2}$. Compounds $12\left(6.7 \mathrm{mg}, t_{R} 19.7 \mathrm{~min}\right)$ and $15\left(12.1 \mathrm{mg}, t_{R} 25.7 \mathrm{~min}\right)$ were obtained from parts $C_{1}$ and $C_{2}$, respectively, by HPLC purification using the Zorbax SB-C $C_{18}$ column with UV detection of $210 \mathrm{~nm}$ and mobile phase of $55 \% \mathrm{MeOH} / \mathrm{H}_{2} \mathrm{O}$ at flow rate of $1.0 \mathrm{~mL} / \mathrm{min}$.

Fraction D was first fractionated on a column $(500 \times 25 \mathrm{~mm})$ of Sephadex LH-20 $(120 \mathrm{~g})$ eluting with $50 \%(300 \mathrm{~mL}), 60 \%(450 \mathrm{~mL})$, and $70 \% \mathrm{MeOH}(200 \mathrm{~mL})$ to give three subfractions $\mathrm{D}_{1}-\mathrm{D}_{3}$, respectively. Subfraction $\mathrm{D}_{1}$ was further separated by the CT-30 column (UV detection: $210 \mathrm{~nm}$; mobile phase: $\mathrm{MeOH} / \mathrm{H}_{2} \mathrm{O}, 62 / 38$; flow rate: $\left.10.0 \mathrm{~mL} / \mathrm{min}\right)$ to give $\mathbf{1 1}\left(15.0 \mathrm{mg}, \mathrm{t}_{\mathrm{R}} 26.8 \mathrm{~min}\right), \mathbf{5}\left(10.8 \mathrm{mg}\right.$, $\mathrm{t}_{\mathrm{R}}$ $36.4 \mathrm{~min}$ ), and 7 (5.3 mg, $\left.\mathrm{t}_{\mathrm{R}} 32.8 \mathrm{~min}\right)$. By using the same Zorbax $\mathrm{SB}-\mathrm{C}_{18}$ column with the same UV detection of $210 \mathrm{~nm}$ and the same flow rate of $1.0 \mathrm{~mL} / \mathrm{min}$, but different mobile phases, compound 6 $\left(5.3 \mathrm{mg}, \mathrm{t}_{\mathrm{R}} 28.0 \mathrm{~min}, \mathrm{MeOH} / \mathrm{H}_{2} \mathrm{O}, 70 / 30\right)$ was purified from subfraction $\mathrm{D}_{2}$ and $\mathbf{8}\left(4.2 \mathrm{mg}, \mathrm{t}_{\mathrm{R}} 17.9 \mathrm{~min}\right.$, $\mathrm{MeOH} / \mathrm{H}_{2} \mathrm{O}, 50 / 50$ ) from subfraction $\mathrm{D}_{3}$. 
Andrastone $\mathrm{C}(\mathbf{1})$ : Colorless monoclinic crystal; molecular formula $\mathrm{C}_{28} \mathrm{H}_{36} \mathrm{O}_{8}$; m.p. $118-120{ }^{\circ} \mathrm{C}$; $[\alpha]_{\mathrm{D}}^{20}+60^{\circ}\left(c\right.$ 0.10, MeOH); UV (MeOH) $\lambda_{\max }(\log \varepsilon) 256$ (3.58) nm; IR (MeOH) $v_{\max } 3526,1736,1716$, $1698,1660,1030 \mathrm{~cm}^{-1} ;{ }^{13} \mathrm{C}$ NMR data (150 MHz, in dimethylsulfoxide- $\left.d_{6}\right)$, Table $1,{ }^{1} \mathrm{H}$ NMR data (600 MHz, in dimethylsulfoxide- $d_{6}$ ), Table 1 ; HRESIMS $m / z 499.2340[\mathrm{M}-\mathrm{H}]^{-}$(calcd for $\mathrm{C}_{28} \mathrm{H}_{35} \mathrm{O}_{8}$, 499.2332), $501.2482[\mathrm{M}+\mathrm{H}]^{+}$(calcd for $\mathrm{C}_{28} \mathrm{H}_{37} \mathrm{O}_{8}, 501.2488$ ), and $523.2308\left[\mathrm{M}+\mathrm{Na}^{+}\right.$(calcd for $\mathrm{C}_{28} \mathrm{H}_{36} \mathrm{NaO}_{8}, 523.2308$ ).

Crystal data of andrastone $\mathrm{C}(\mathbf{1}): \mathrm{C}_{28} \mathrm{H}_{36} \mathrm{O}_{8}(M=500.57 \mathrm{~g} / \mathrm{mol})$ : monoclinic, space group $\mathrm{P} 2{ }_{1}$ (no. 4), $a=8.58899(11) \AA, b=8.86131(11) \AA, c=16.7937(2) \AA, \beta=96.8005(12)^{\circ}, V=1269.17(3) \AA^{3}, Z=2$, $T=293(2) \mathrm{K}, \mu(\mathrm{Cu} \mathrm{K} \alpha)=0.784 \mathrm{~mm}^{-1}$, Dcalc $=1.310 \mathrm{~g} / \mathrm{cm}^{3}, 7640$ reflections measured $\left(5.3^{\circ} \leq 2 \Theta \leq\right.$ $\left.147.088^{\circ}\right), 4316$ unique $\left(R_{\text {int }}=0.0172, R_{\text {sigma }}=0.0240\right)$ which were used in all calculations. The final $R_{1}$ was 0.0311 (I $>2 \sigma(\mathrm{I})$ ) and $w R_{2}$ was 0.0866 (all data). The crystal data and structure refinement parameters of $\mathbf{1}$ were also reported in Table S8. Crystallographic data of andrastone C (1) has been deposited at the Cambridge Crystallographic Data Centre (CCDC Number: 1979103). Copies of the data can be obtained free of charge from Cambridge Crystallographic Data Centre, 12, Union Road, Cambridge CB2 1EZ, U.K. [fax (+44)1223-336-033; or e-mail: data_request@ccdc.cam.ac.uk).

Andrastone B (2): Colorless orthorhombic crystal; molecular formula $\mathrm{C}_{28} \mathrm{H}_{36} \mathrm{O}_{9}$; m.p. $130-134{ }^{\circ} \mathrm{C}$ $[\alpha]_{\mathrm{D}}{ }^{20}-88^{\circ}\left(c\right.$ 0.02, MeOH); ${ }^{13} \mathrm{C}$ NMR data $\left(150 \mathrm{MHz}\right.$, in MeOH- $\left.d_{4}\right)$, Table S2, ${ }^{1} \mathrm{H}$ NMR data $(600 \mathrm{MHz}$, in $\left.\mathrm{MeOH}-d_{4}\right)$, Table S3; HRESIMS $m / z 515.2286[\mathrm{M}-\mathrm{H}]^{-}\left(\right.$calcd for $\left.\mathrm{C}_{28} \mathrm{H}_{35} \mathrm{O}_{9}, 515.2281\right)$ and 539.2253 $[\mathrm{M}+\mathrm{Na}]^{+}$(calcd for $\mathrm{C}_{28} \mathrm{H}_{36} \mathrm{NaO}_{9}, 539.2257$ ).

Crystal data of andrastone $\mathrm{B}(2): \mathrm{C}_{28} \mathrm{H}_{38} \mathrm{O}_{10}(M=534.58 \mathrm{~g} / \mathrm{mol})$ : orthorhombic, space group $\mathrm{P} 2{ }_{1} 2{ }_{1} 2_{1}$ (no. 19), $a=9.1880$ (3) $\AA, b=13.2582(5) \AA, c=22.8448(6) \AA, V=2782.87(16) \AA^{3}, Z=4, T=293(2)$ $\mathrm{K}, \mu(\mathrm{Cu} \mathrm{K} \alpha)=0.802 \mathrm{~mm}^{-1}$, Dcalc $=1.276 \mathrm{~g} / \mathrm{cm}^{3}, 13131$ reflections measured $\left(7.71^{\circ} \leq 2 \Theta \leq 147.056^{\circ}\right)$, 5414 unique $\left(R_{\text {int }}=0.0263, R_{\text {sigma }}=0.0313\right)$ which were used in all calculations. The final $R_{1}$ was 0.0438 (I $>2 \sigma(\mathrm{I}))$ and $w R_{2}$ was 0.1180 (all data). The crystal data and structure refinement parameters of 3 were also reported in Table S15. Crystallographic data of andrastone B (2) has been deposited at the Cambridge Crystallographic Data Centre (CCDC Number: 1976943). Copies of the data can be obtained free of charge from Cambridge Crystallographic Data Centre, 12, Union Road, Cambridge CB2 1EZ, U.K. [fax (+44)1223-336-033; or e-mail: data_request@ccdc.cam. ac.uk).

\subsection{Antimicrobial Active Assay}

The antimicrobial activities of all isolated compounds against methicillin-resistant Staphylococcus aureus (MRSA), Escherichia coli, and Candida albicans were tested by the micro-broth dilution method as describe in the previous study [37] with little modification. Vancomycin, gentamicin, and amphotericin B were used as positive controls. Briefly, 96-well plates were used to make dilutions of the tested compounds. The first serial dilution was followed to get a broad range of concentration for each compound. Initial concentration was $200 \mu \mathrm{g} / \mathrm{mL}$ and then by serial dilution with $50 \%$ DMSO, other concentrations of $100,50,25,12.5,6.25,3.125$, and $1.5625 \mu \mathrm{g} / \mathrm{mL}$ were achieved. The final volume was $200 \mu \mathrm{L}$. After that $2 \mu \mathrm{L}$ from $10^{8} \mathrm{cfu} / \mathrm{mL}$ of culture was added and the plates were incubated at $37^{\circ} \mathrm{C}$ for $12 \mathrm{~h}$ overnight. Minimum inhibitory concentration (MIC) that inhibited the growth of microorganisms and minimum bactericidal concentration (MBC) that completely killed microorganisms were recorded. Finally, based on results obtained, specific concentrations of each compound were prepared to get more accurate values of MIC and MBC.

\subsection{Antiproliferative Active Assay}

The Sulforhodamine B (SRB) assay [38] was applied to evaluate the activity of the tested compounds in inhibiting the proliferation of human glioma U251 and U87MG cells. Doxorubicin (DOX) was used as a positive control. Human glioma U251 and U87MG cells were cultured in DMEM (Dulbecco's Modified Eagle Medium, Gibco) and MEM (Minimum Essential Medium, Gibco) and with 10\% FBS (Fetal Bovine Serum, PAA Laboratories Inc.), respectively. All cells were incubated in a 5\% 
$\mathrm{CO}_{2}$ humidified incubator at $37^{\circ} \mathrm{C}$ and the cultured cells after the third generation were used for the experiments.

\section{Conclusions}

One novel meroterpenoid, named andrastone $C$, and fifteen known compounds with diverse structural classes, were discovered and characterized from the culture of a Mariana Trench sediment-associated fungus Penicillium sp. SY2107 in rice medium. Andrastone C and most of the known compounds showed antimicrobial activities against MRSA, E. coli, and C. albicans. (Z)-N-(4-hydroxystyryl) formamide exhibited antiglioma activity. Data from this study enriched the chemical and bioactive diversities of the secondary metabolites from the Mariana Trench-sourced microorganisms.

Supplementary Materials: The following are available online at http://www.mdpi.com/1660-3397/18/5/258/s1, Colonies of Penicillium sp. SY2107, Figure S2: ITS rDNA sequence of Penicillium sp. SY2107, Table S1: Score statistics for sequence alignment of strain SY2107, Table S2-S7: ${ }^{13} \mathrm{C}$ and ${ }^{1} \mathrm{H}$ NMR data of compounds 2-16, Figure S3-S22: NMR and HRESIMS spectra of andrastone C (1), Table S8-S14: Crystal data of X-ray diffraction of andrastone C (1), Table S15-S21: Crystal data of X-ray diffraction of andrastone B (2).

Author Contributions: S.K. conducted the isolation and culture of stain SY2107 as well as the isolation and structural elucidation of the isolated compounds; L.Q. performed the bioactive assay; W.Y. conducted the NMR experiments, X.-Y.L. and Z.Z. designed and supervised the experiments and wrote the manuscript. All authors have read and agreed to the published version of the manuscript.

Funding: This research was funded by the National Key R\&D Program of China (grant No. 2018YFC0310600) and the National Natural Science Foundation of China (No. 81773587).

Acknowledgments: The authors thank Jiasong Fang at College of Marine Sciences, Shanghai Ocean University and Xuan Li at Institute of Plant Physiology and Ecology, Chinese Academy of Sciences, for providing the sediment sample collected from Mariana Trench at depth $11000 \mathrm{~m}$.

Conflicts of Interest: The authors declare no conflict of interest.

\section{References}

1. Blunt, J.W.; Carroll, A.R.; Copp, B.R.; Davis, R.A.; Keyzers, R.A.; Prinsep, M.R. Marine natural products. Nat. Prod. Rep. 2018, 35, 8-53. [CrossRef]

2. Carroll, A.R.; Copp, B.R.; Davis, R.A.; Keyzers, R.A.; Prinsep, M.R. Marine natural products. Nat. Prod. Rep. 2019, 36, 122-173. [CrossRef] [PubMed]

3. Pereira, R.B.; Evdokimov, N.M.; Lefranc, F.; Valentão, P.; Kornienko, A.; Pereira, D.M.; Andrade, P.B.; Gomes, N.G.M. Marine-derived anticancer agents: Clinical benefits, innovative mechanisms, and new targets. Mar. Drugs 2019, 17, 329. [CrossRef] [PubMed]

4. Shinde, P.; Banerjee, P.; Mandhare, A. Marine natural products as source of new drugs: A patent review (2015-2018). Expert Opin. Ther. Pat. 2019, 29, 283-309. [CrossRef] [PubMed]

5. Matulja, D.; Wittine, K.; Malatesti, N.; Laclef, S.; Turks, M.; Kolympadi, M.; Ambrožić, G.; Markovic, D. Marine natural products with high anticancer activities. Curr. Med. Chem. 2020, 27, 1243-1307. [CrossRef] [PubMed]

6. Skropeta, D. Deep-sea natural products. Nat. Prod. Rep. 2008, 25, 1131-1166. [CrossRef] [PubMed]

7. Skropeta, D.; Wei, L. Recent advances in deep-sea natural products. Nat. Prod. Rep. 2014, 31, 999-1025. [CrossRef] [PubMed]

8. Pilkington, L.I. A Chemometric analysis of deep-sea natural products. Molecules 2019, 24, 3942. [CrossRef]

9. Sun, C.; Mudassir, S.; Zhang, Z.; Feng, Y.; Chang, Y.; Che, Q.; Gu, Q.; Zhu, T.; Zhang, G.; Li, D. Secondary metabolites from deep-sea derived microorganisms. Curr. Med. Chem. 2019. [CrossRef]

10. Prieto-Davó, A.; Villarreal-Gómez, L.J.; Forschner-Dancause, S.; Bull, A.T.; Stach, J.E.; Smith, D.C.; Rowley, D.C.; Jensen, P.R. Targeted search for actinomycetes from nearshore and deep-sea marine sediments. FEMS Microbiol. Ecol. 2013, 84, 510-518. [CrossRef]

11. Russo, P.; Del Bufalo, A.; Fini, M. Deep sea as a source of novel-anticancer drugs: Update on discovery and preclinical/clinical evaluation in a systems medicine perspective. EXCLI J. 2015, 14, 228-236. [PubMed] 
12. Jensen, P.R.; Moore, B.S.; Fenical, W. The marine actinomycete genus Salinispora: A model organism for secondary metabolite discovery. Nat. Prod. Rep. 2015, 32, 738-751. [CrossRef] [PubMed]

13. Di, K.; Lloyd, G.K.; Abraham, V.; MacLaren, A.; Burrows, F.J.; Desjardins, A.; Trikha, M.; Bota, D.A. Marizomib activity as a single agent in malignant gliomas: Ability to cross the blood-brain barrier. Neuro Oncol. 2016, 18, 840-848. [CrossRef] [PubMed]

14. Badros, A.; Singh, Z.; Dhakal, B.; Kwok, Y.; MacLaren, A.; Richardson, P.; Trikha, M.; Hari, P. Marizomib for central nervous system-multiple myeloma. Br. J. Haematol. 2017, 177, 221-225. [CrossRef] [PubMed]

15. Peoples, L.M.; Grammatopoulou, E.; Pombrol, M.; Xu, X.; Osuntokun, O.; Blanton, J.; Allen, E.E.; Nunnally, C.C.; Drazen, J.C.; Mayor, D.J.; et al. Microbial community diversity within sediments from two geographically separated hadal trenches. Front. Microbiol. 2019, 10, 347. [CrossRef]

16. Liu, J.; Zheng, Y.; Lin, H.; Wang, X.; Li, M.; Liu, Y.; Yu, M.; Zhao, M.; Pedentchouk, N.; Lea-Smith, D.J.; et al. Proliferation of hydrocarbon-degrading microbes at the bottom of the Mariana Trench. Microbiome 2019, 7, 47. [CrossRef]

17. Chen, L.; Chai, W.Y.; Wang, W.L.; Song, T.F.; Lian, X.Y.; Zhang, Z.Z. Cytotoxic bagremycins from mangrove-derived Streptomyces sp. Q22. J. Nat. Prod. 2017, 80, 1450-1456. [CrossRef]

18. Chen, M.X.; Chai, W.Y.; Song, T.F.; Ma, M.Z.; Lian, X.Y.; Zhang, Z.Z. Anti-glioma natural products downregulating tumor glycolytic enzymes from marine actinomycete Streptomyces sp. ZZ406. Sci. Rep. 2018, 8, 72. [CrossRef]

19. Song, T.F.; Chen, M.X.; Ge, Z.W.; Chai, W.Y.; Li, X.C.; Zhang, Z.Z.; Lian, X.Y. Bioactive penicipyrrodiether A, an adduct of GKK1032 analogue and phenol A derivative, from a marine-sourced fungus Penicillium sp. ZZ380. J. Org. Chem. 2018, 83, 13395-13401. [CrossRef]

20. Song, T.F.; Tang, M.M.; Ge, H.J.; Chen, M.X.; Lian, X.Y.; Zhang, Z.Z. Novel bioactive penicipyrroether A and pyrrospirone J from the marine-derived Penicillium sp. ZZ380. Mar. Drugs 2019, 17, 292. [CrossRef]

21. Zhang, D.; Yi, W.W.; Ge, H.Z.; Zhang, Z.Z.; Wu, B. Bioactive streptoglutarimides A-J from the marine-derived Streptomyces sp. ZZ741. J. Nat. Prod. 2019, 82, 2800-2808. [CrossRef] [PubMed]

22. Yang, X.W.; Xie, C.L.; Xia, J.M.; Luo, Q.; Luo, Z.H.; Shao, Z.Z. Heteroterpene Compound Derived from Penicillium and Its Preparation Method for Anti-Tumor Medicament. CN Patent 109942658 A 20190628, 2019.

23. Xie, C.L.; Xia, J.M.; Lin, T.; Lin, Y.J.; Lin, Y.K.; Xia, M.L.; Chen, H.F.; Luo, Z.H.; Shao, Z.Z.; Yang, X.W. Andrastone A from the deep-sea-derived fungus Penicillium allii-sativi acts as an inducer of Caspase and RXR $\alpha$-dependent apoptosis. Front. Chem. 2019, 7, 692. [CrossRef] [PubMed]

24. Umehara, K.; Yoshida, K.; Okamoto, M.; Iwami, M.; Tanaka, H.; Kohsaka, M.; Imanaka, H. Studies on WF-5239, a new potent platelet aggregation inhibitor. J. Antibiot. 1984, 37, 469-474. [CrossRef]

25. Qu, P.; Liu, P.P.; Fu, P.; Wang, Y.; Zhu, W.M. Secondary metabolites of halotolerant fungus Penicillium chrysogenum HK14-01 from the Yellow River Delta area. Acta Microbiol. Sin. 2012, 52, 1103-1112.

26. Wang, C.; Gao, Y.K.; Lei, F.H.; Tan, X.C.; Shen, L.Q.; Gao, C.H.; Yi, X.X.; Li, X.Y. A new glycosyl ester isolated from marine-derived Penicillium sp. Chin. Trad. Herbal Drugs 2019, 50, 2518-2523.

27. Takahashi, C.; Matsushita, T.; Doi, M.; Minoura, K.; Shingu, T.; Kumeda, Y.; Numata, A. Fumiquinazolines A-G, novel metabolites of a fungus separated from a Pseudolabrus marine fish. J. Chem. Soc. Perkin Trans. 1995, 18, 2345-2353. [CrossRef]

28. Wang, F.Z.; Fang, Y.C.; Zhu, T.J.; Zhang, M.; Lin, A.Q.; Gu, Q.Q.; Zhu, W.M. Seven new prenylated indole diketopiperazine alkaloids from holothurian-derived fungus Aspergillus Fumigatus. Tetrahedron 2008, 64, 7986-7991. [CrossRef]

29. Zhang, L.M.; Li, Z.L.; Bai, J.; Wu, X.; Wang, Y.; Hua, H.M. Metabolites of Aspergillus sp. HT-2. Chin. Pharm. J. 2011, 46, 1154-1158.

30. Peter, B.; Christoph, T. Isolation and structure of pseurotin A, a microbial metabolite of Pseudeurotium ovalis Stolk with an unusual heterospirocyclic system. Helvetica Chim. Acta 1981, 64, 304-315.

31. Lin, X.P.; Wu, Q.Y.; Yu, Y.Y.; Liang, Z.; Liu, Y.H.; Zhou, L.L.; Tang, L.; Zhou, X.F. Penicilliumin B, a novel sesquiterpene methylcyclopentenedione from a deep sea-derived Penicillium strain with renoprotective activities. Sci. Rep. 2017, 7, 10757. [CrossRef]

32. Ji, Y.; Xin, Z.; He, H.; Gao, S. Total synthesis of viridin and viridiol. J. Am. Chem. Soc. 2019, 141, 16208-16212. [CrossRef] 
33. Jongrungruangchok, S.; Kittakoop, P.; Yongsmith, B.; Bavovada, R.; Tanasupawat, S.; Lartpornmatulee, N.; Thebtaranonth, Y. Azaphilone pigments from a yellow mutant of the fungus Monascus kaoliang. Phytochemistry 2004, 65, 2569-2575. [CrossRef] [PubMed]

34. Li, S.; Wei, M.; Chen, G.; Lin, Y. Two new dihydroisocoumarins from the endophytic fungus Aspergillus sp. collected from the South China Sea. Chem. Nat. Comp. 2012, 48, 371-373. [CrossRef]

35. Zuo, M.X.; Zhou, Y.L.; Xu, Y.C.; Liu, W.; Zhu, W.M.; Wang, L.P. Secondary metabolites of Aspergillus fumigatus GZWMJZ-152 cultivated on Camellia seed cake medium. Mycosystema 2019, 38, 264-271.

36. Liu, R.; Zhu, W.M.; Zhang, Y.P.; Zhu, T.J.; Liu, H.B.; Fang, Y.C.; Gu, Q.Q. A new diphenyl ether from marine-derived fungus Aspergillus sp. B-F-2. J. Antibiot. 2006, 59, 362-365. [CrossRef] [PubMed]

37. Teng, X.C.; Zhuang, Y.B.; Wang, Y.; Liu, P.P.; Xu, Z.H.; Zhu, W.M. Secondary metabolites from Penicillium sp. gxwz406 symbiotic with the gorgonian Echinogorgia flora. Chin. J. Mar. Drugs 2010, 29, 11-15.

38. Fu, H.C.; Zhao, W.Y.; Zhong, H.M.; Hong, K.; Gu, Q.Q.; Zhu, W.M. Bioactive alkaloids from sponge-derived actinomyces sh6004. Chin. J. Mar. Drugs 2008, 27, 14-20.

39. Ye, X.W.; Anjum, K.; Song, T.F.; Wang, W.L.; Yu, S.R.; Huang, H.C.; Lian, X.Y.; Zhang, Z.Z. A new curvularin glycoside and its cytotoxic and antibacterial analogues from marine actinomycete Pseudonocardia sp. HS7. Nat. Prod. Res. 2016, 30, 1156-1161. [CrossRef]

40. Xin, W.X.; Ye, X.W.; Yu, S.R.; Lian, X.Y.; Zhang, Z.Z. New capoamycin-type antibiotics and polyene acids from marine Streptomyces fradiae PTZ0025. Mar. Drugs 2012, 10, 2388-2402. [CrossRef]

(C) 2020 by the authors. Licensee MDPI, Basel, Switzerland. This article is an open access article distributed under the terms and conditions of the Creative Commons Attribution (CC BY) license (http://creativecommons.org/licenses/by/4.0/). 